\title{
Assessment of Vulnerability and Community Preparedness Against Flood Disaster During Covid-19 Pandemic Period in Semarang City
}

\author{
Ananto Aji ${ }^{1, *}$ Rahma Hayati ${ }^{2}$ Andi Irwan Benardi ${ }^{3,}$ Hemy Bayu Laksono, \\ Neza Zakiyah $^{5,}$ Wahyu Fauziyah ${ }^{6}$, Bambang Eko Widyatmoko ${ }^{7}$ \\ 1,2,3,4,5,6,7 Geografi, Fakultas Ilmu Sosial, Universitas Negeri Semarang. \\ *Corresponding author. Email: ajiananto@mail.unnes.ac.id ${ }^{l}$
}

\begin{abstract}
Semarang is one of the cities with many threats of natural disasters that have an impact on human life, can bring harm and can also be good. One of the natural disasters that often occurs and has a direct impact on human life is flood disaster. The purpose of this study was to determine the extent of flooding from 2020-2021 in Semarang City and changes in the socioeconomic conditions of people affected by floods and people affected by Covid-19. This study used several data collection methods including a survey of topographical conditions and also interviewing respondents related to socio-economic conditions. The research was conducted in the city of Semarang as a potential flood area. The sample was selected using purposive sampling, the criteria for the age of 18-39 years or commonly referred to as the millennial generation. Field observations were carried out with guided questionnaires to collect data on the role of the government, community, private sector and non-governmental organizations in flood management. Data were analyzed based on demographics, areas, and understanding of flood disasters. After that the data is processed and processed into spatial data so that it can be in the form of vulnerability maps and flood disaster preparedness levels in the city of Semarang. Results of the study it can be concluded that the area of flooding in the city of Semarang in 2020-2021 is 24,443 hectares and the category of disaster risk is classified as having a high impact on the socio-economic conditions of the community.
\end{abstract}

Keywords: Flood, Vulnerability, Preparedness, Covid-19, Disaster Mitigation.

\section{INTRODUCTION}

The increase in the risk of flood disasters is getting higher not only due to high groundwater consumption, but there are many factors that cause an increase in the risk of flooding itself, including antopogenic factors consisting of first changes in land use, excessive groundwater consumption, and also development of infrastructure which causes higher building loads. Second is the geological factor, namely the geological constituent of Semarang City which consists of clay deposits, especially in the northern part of Semarang or in the coastal areas. The development of Semarang City itself is concentrated in the northern region, and in the southern part itself is designated as a conservation area because of its hilly topography [1].

The problem increases when the conditions for the spread of Covid-19 are not over. The disease caused by Corona Virus Disease 2019 (Covid-19) is a virus that comes from animals and has never attacked humans before. The world organization working in the world of health defines this virus as a global epidemic or pandemic because of the very rapid and massive spread that almost all countries have experienced this phenomenon. Covid-19 is spreading contagiously. This means a very fast rate of spread from individual to individual in a network, such as disasters and flu [2]. 
During this pandemic conditions will be worse when there is a flood. Flood management protocols during the Covid-19 pandemic must be implemented so that a new epicenter does not occur and reduces the burden on the government. The government and local governments are the parties most responsible for disaster risk management. It becomes a necessity that the presence of the state is important in disaster management. This is because disaster is a threat to human life. So local governments are also given the authority by the central government to be able to cope with disasters in their regions. This concerns the responsibility of the Regent / Mayor to create disaster response in the region (Heryati, 2020) [4].

The level of knowledge, attitudes, skills and work motivation must be cultivated in the surrounding community and local government to solve current problems. Various efforts should be made to achieve this goal. education which includes formal education such as schools, non-formal education, which is mostly carried out by agencies related to nature conservation, such as NGOs or government agencies that are directly related to businesses which in various groups can be used as a forum to increase community preparedness in overcoming floods and the impact it causes [5].

Disaster-related agencies in the regions, namely $\mathrm{BPBD}$, have the function of reducing disaster risk by coordinating with various related parties. BPBD collaborates with various agencies to monitor as well as become a leader in disaster management. Steps such as creating programs related to disasters in the community are expected to be able to reduce the impact caused by disasters.

This study then aims to investigate the phenomenon of flood expansion using the Expansion Modeling of which areas are flooded as well as a study of the Covid pandemic on flood disasters in the city of Semarang. This is in line with the UNNES research strategic plan which leads to disaster studies in disaster management and mitigation, because floods are one of the natural disasters that can threaten people's lives. In addition, this research is expected to be able to provide input on development policies carried out by the government in areas that are at risk of flooding.

\section{METHODS}

In connection with this research, the writer uses descriptive qualitative research. The descriptive research in question is to collect information about the distribution of flood hazards in the city of Semarang using field observation methods and behavioral surveillance of research subjects in a certain period with changes in the socio-economic conditions of the community affected by floods and covid-19. Meanwhile, qualitative descriptive research aims to describe all circumstances or conditions related to the research subject based on what the researcher observes. In this study, the author tries to explain the preparedness carried out by the Brebes Regency Government to face floods during the Covid-19 pandemic. Data collection was carried out using observation, documentation, and interview techniques. The sampling technique used is purposive sampling by digging up information that will be the basis of the theory and design used by the researcher. The informants in this study were from elements of regulators, operators and the community. Qualitative data analysis uses an interactive model which explains that the analysis technique consists of data collection, data condensation, data presentation and drawing conclusions. The operationalization of the concept of preparedness uses the approach summarized by the author covering four aspects, namely a) The distribution of flood hazards in the city of Semarang b) Knowledge and attitudes in dealing with disasters; c) Emergency response plan; d) Early warning system; e) Resources that support implementation.

\section{RESULTS AND DISCUSSION \\ 3.1. Distribution of flood hazard in Semarang City}

Physically in terms of geological formations, Semarang City is located in the Kalibiuk Formation which is part of the Notopuro Formation which is Quaternary. Most of the city of Semarang, especially in the northern part, is an area formed from the Kaligarang Alluvial Fan which reaches 80 meters in thickness [6]. The problem of disasters in Indonesia, especially in the city of Semarang is quite complicated because they occur in remote areas and cannot find vulnerable people, who are located far from the central and local governments. Therefore, the new paradigm for disaster management must be able to address these problems, towards community-based disaster management, which are people / communities who are independent, able to recognize hazards in the environment, and able to help themselves during a critical time of a disaster. Based on the above background, the author wishes to compile a study on the level of community preparedness in overcoming floods in the city of Semarang, Indonesia. Based on background, the purpose this study is to identify and community and their relationship with their knowledge, preparedness and level of action against disasters. 


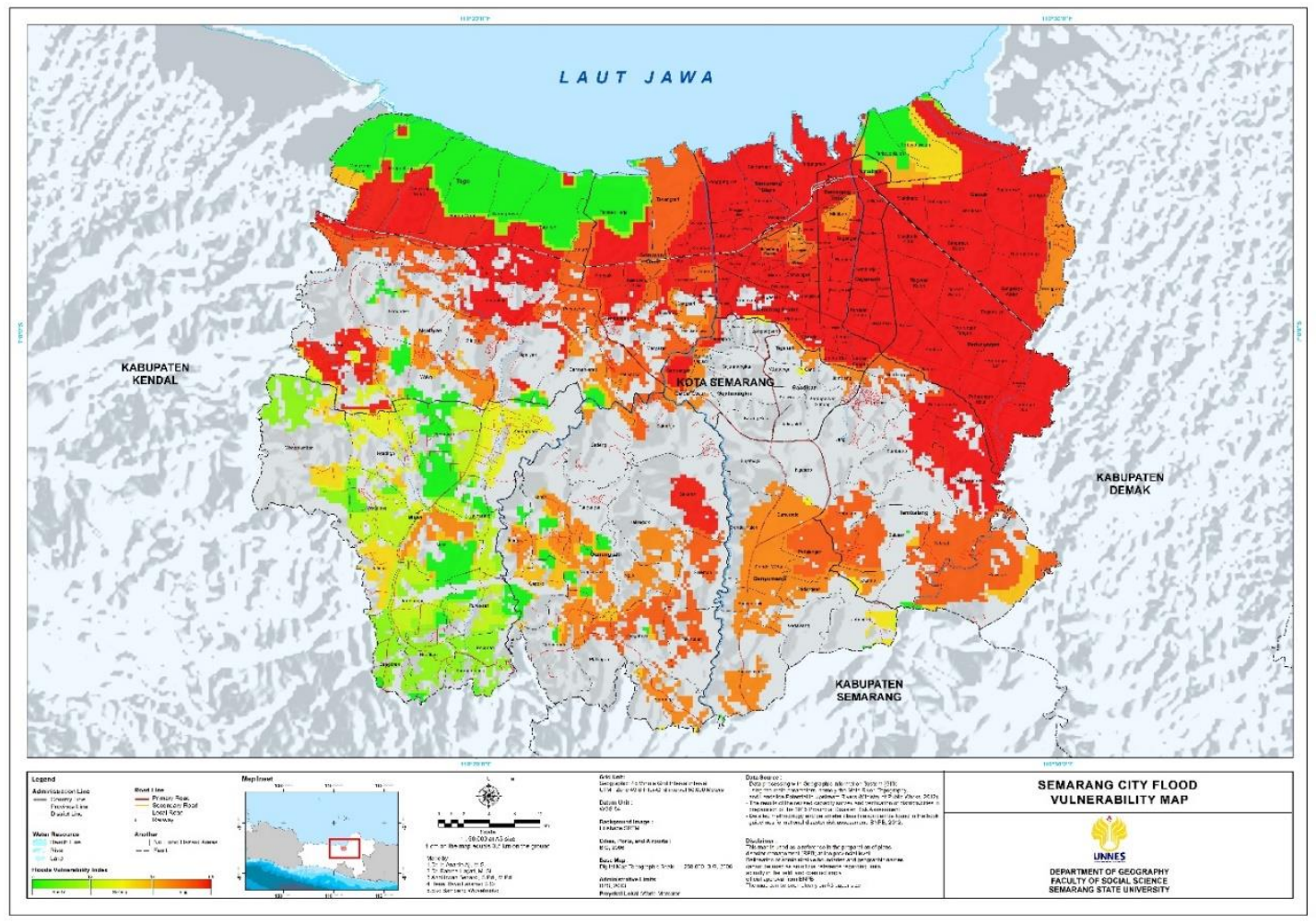

Figure 1. Flood Vulnerability Map in Semarang City

From the map above, the area of the city of Semarang which has a high risk of flooding is in the northern part of Semarang City because it has a sloping topography of approximately 0-5 meters above sea level, which is located in Tugu District, West Semarang District, North Semarang District, Genuk District and
District Pedurungan. Whereas areas that have low danger are in the southern part of Semarang City, which is located in Mijen District, Gunungpati District, Banyumanik District, Ngaliyan District and Candisari District with an altitude of approximately 200-300 meters above sea level and has a steep topography

Table 1. Flood Hazard Map in Semarang City 2020

\begin{tabular}{|c|c|c|c|c|c|c|}
\hline \multirow{3}{*}{ DISTRICTS } & \multirow{3}{*}{$\begin{array}{l}\text { JHAZARD } \\
\text { TYPES }\end{array}$} & \multicolumn{5}{|c|}{ DANGER } \\
\hline & & \multicolumn{3}{|c|}{ AREA OF DANGER (HA) } & \multirow{2}{*}{$\begin{array}{l}\text { TOTAL } \\
\text { AREA } \\
\text { (Hektare) }\end{array}$} & \multirow[b]{2}{*}{ CLASS } \\
\hline & & LOW & MIDLE & HIGH & & \\
\hline MUJEN & FLOOD & 3.349 & 159 & 3 & 3.511 & LOW \\
\hline GUNUNG PATI & FLOOD & 1.925 & 71 & - & 1.996 & LOW \\
\hline $\begin{array}{l}\text { BANYUMANIK } \\
\text { GAJAH }\end{array}$ & FLOOD & 1.223 & 4 & - & 1.227 & LOW \\
\hline \multirow{2}{*}{$\begin{array}{l}\text { GAJAH } \\
\text { MUNGKUR } \\
\text { SEMARANG } \\
\text { SELATAN }\end{array}$} & FLOOD & 152 & 64 & 6 & 222 & MIDLE \\
\hline & FLOOD & 258 & 258 & 46 & 562 & High \\
\hline CANDISARI & FLOOD & 82 & - & - & 82 & LOW \\
\hline TEMBALANG & FLOOD & 1.576 & 492 & 16 & 2.084 & MIDLE \\
\hline PEDURUNGGAN & FLOOD & 155 & 1.394 & 706 & 2.255 & $\mathrm{HIGH}$ \\
\hline GENUK & FLOOD & 65 & 1.842 & 800 & 2.707 & $\mathrm{HIGH}$ \\
\hline $\begin{array}{l}\text { GAYAMSARI } \\
\text { SEMARANG }\end{array}$ & FLOOD & - & 436 & 196 & 632 & $\mathrm{HIGH}$ \\
\hline $\begin{array}{l}\text { TIMUR } \\
\text { SEMARANG }\end{array}$ & FLOOD & - & 319 & 255 & 574 & $\mathrm{HIGH}$ \\
\hline $\begin{array}{l}\text { UTARA } \\
\text { SEMARANG }\end{array}$ & FLOOD & 111 & 695 & 319 & 1.125 & $\mathrm{HIGH}$ \\
\hline $\begin{array}{l}\text { TENGAH } \\
\text { SEMARARG }\end{array}$ & FLOOD & 2 & 404 & 133 & 539 & $\mathrm{HIGH}$ \\
\hline BARAT & FLOOD & 443 & 796 & 718 & 1.957 & HIGH \\
\hline TUGU & FLOOD & 417 & 682 & 1.869 & 2.968 & $\mathrm{HIGH}$ \\
\hline \multirow[t]{2}{*}{ NGALIYAN } & FLOOD & 1.791 & 170 & 21 & 1.982 & Low \\
\hline & & & & & 24.423 & $\mathrm{HIGH}$ \\
\hline
\end{tabular}

Source: Field Data, 2020 


\subsection{Knowledge and Attitude in Facing Disasters}

Knowledge is the key in implementing preparedness. Based on this knowledge, the government and society can take appropriate actions in the face of disasters. Apart from being a provider of community needs, the government is a stakeholder who acts as a source of disaster knowledge [7]. Government knowledge about the risk of flood disasters is the basis for showing concern for the community and becoming a step in policy making. Semarang City Government has experience with floods almost every year. Based on this experience, the Semarang City Government is better prepared to face the threat of the next flood. The result of this knowledge encourages the Semarang City Government to act in dealing with floods. The Semarang City Government has held a coordination meeting attended by disaster stakeholders in November 2020 for hydrometeorological disaster preparedness during the pandemic. In addition, there is a disaster-prone map. The map includes the threat of flood, drought, fire, tornado, volcanic eruption abrasion, earthquakes, landslides, and a map of the capacity of Semarang City.

Meanwhile, to disseminate knowledge about the threat of floods, the Semarang City Government conducts outreach in schools and communities in floodprone areas. This socialization activity is carried out every approaching the rainy season by utilizing local wisdom, making brochures, billboards, films related to flood disasters and discussions that discuss flood risk reduction. Although the socialization of the dangers of Covid-19 has been carried out through the Covid-19 task force by making brochures, installing billboards in schools and village head offices, and using loudspeakers on traffic lights. However, in the RPB document, there is no plan to handle Covid-19 during the pre-disaster period.

This activity has the intention of making the public and students know from an early age the potential threat of floods and Covid-19 in the area. This statement is reinforced by the results of research that the socialization of disasters has a significant impact on public knowledge and awareness. Plus the results of the research which explained that before providing counseling, the level of community knowledge was in the sufficient category. However, after providing counseling, the level of public knowledge about floods was in a good category.

The attitude of the Semarang City Government in suppressing cases of the spread of Covid-19 is tracing, tracking and testing. Tracing, tracking, and testing efforts to detect the spread of Covid-19 cases in the city of Semarang are continuing. In August 2020 there are 38 health centers spread across 17 districts in Semarang. Testing activities that are carried out thoroughly and routinely can provide accurate data to stakeholders to be able to provide the right policies. The policy is used to identify affected and potential affected people so that they can be separated, thereby reducing the possibility of infecting others [8].

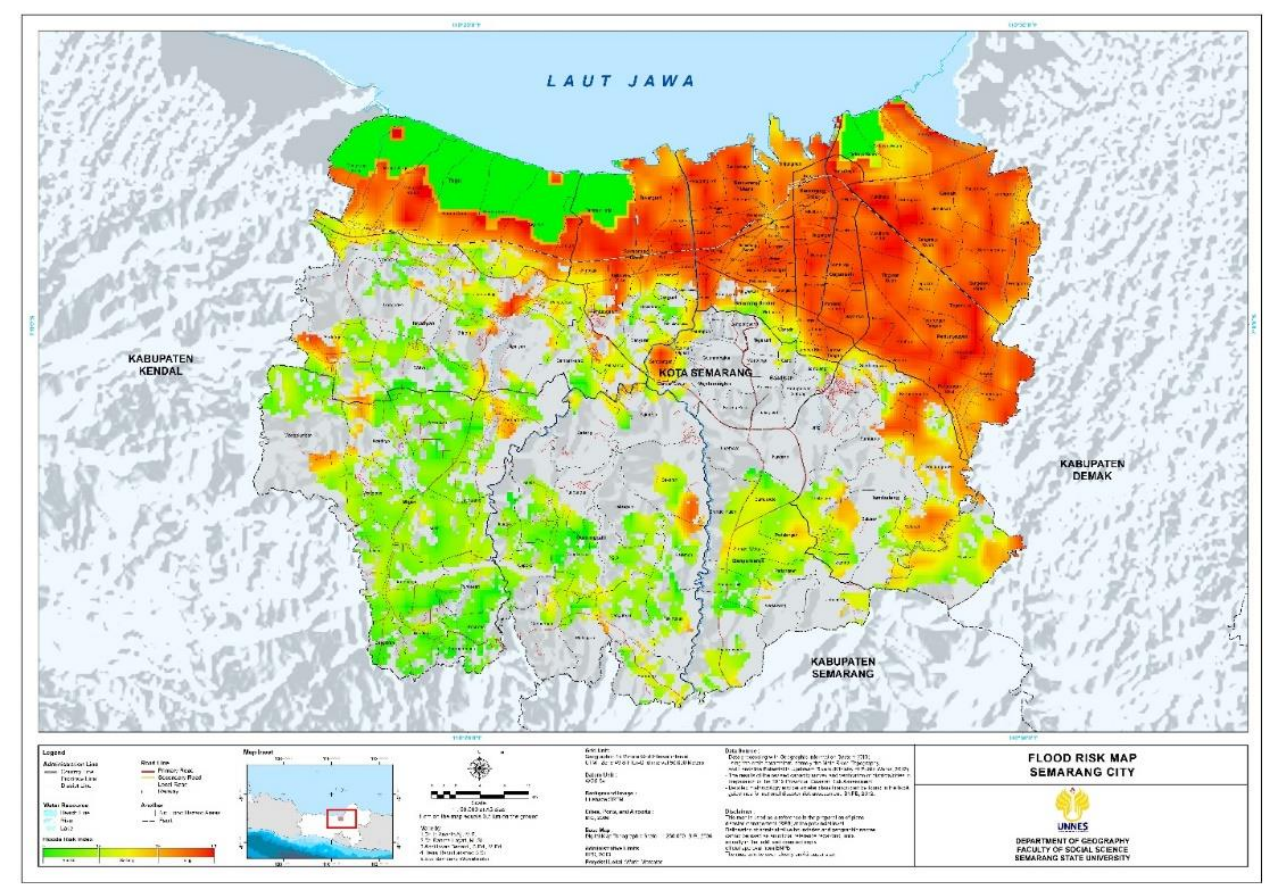

Figure 2. Flood Risk Map in Semarang City 


\subsection{Emergency Response Plan}

An emergency response plan is a step activity carried out to search and rescue victims effectively and efficiently when a disaster occurs. This plan is important to implement, especially on the first day of a disaster and there has been no outside assistance. So the plan becomes an important part of preparedness, especially with regard to the evacuation of victims. There are three types of response actions that can be taken, such as procuring first aid equipment, making modifications to living quarters, and procuring alternative lighting equipment.

Although the Semarang City Government has created evacuation routes for flood disasters in floodprone areas. However, this number is still very limited. Meanwhile for the plan for the evacuation location, the Semarang City BPBD has prepared a District Office and GOR. However, they have not prepared facilities used for evacuation such as family rooms to provide social distancing among refugees. Meanwhile, for health facilities during the emergency response, BPBD has coordinated with the Semarang City Health Office. In the current situation of the Covid-19 crisis, there is a tendency that health tends to focus too much on the Covid-19 issue so that it forgets to include elements of natural disasters in the Covid-19 handling strategy. Moreover, because the budget sources used by both of them and the executor of the task are relatively the same [9].

\subsection{Early Warning System}

Early warning is a series of activities to provide warnings that can reach the entire community and be conveyed quickly to the community regarding the possibility of a disaster by authorized institutions using clear messages and easy-to-understand information to save human lives (BNPB 2012; ISDR, 2006). Apart from knowledge of disasters and preparedness attitudes, early warning systems must be an important point in determining the preparedness of a group or institution in facing the threat of disaster [10].

Based on the results of interviews with the Head of the Preparedness and Prevention Division of the Semarang City BPBD and the author's observations indicate that the early warning system is still in process submitting to BNPB. So far, the early warning system implemented by the Semarang City Government is still conventional, namely using loudspeakers, HTs and telephones. There is no more modern flood early warning system available. Early Warning System (EWS) tool, but what becomes the implementation is the commitment of the local government to protect the community.

On the other hand, the Head of the Semarang City BPBD has ordered its members to monitor the river water level in several river locations such as the Pemali River and Cisanggarung. The main task of this employee is to observe the condition of rivers and rain in their area to report on the development of river water levels on a regular basis. Not only that, the city government of Semarang has built a water level monitoring device that is used to see the condition of river water levels. The monitors are installed on the river bank with different colored markings, namely blue, yellow and red. Good governance and institutions will provide success for implementing an early warning system. Providing warning services based on scientific research, continuous monitoring of warning signs and warnings that operate 24 hours to the public are at the core of the preparedness system by local governments.

\subsection{Resources Supporting Implementation}

Simulation is a step to present experiences that have occurred by utilizing artificial conditions. This is useful for understanding concepts, principles and skills. Simulation is one of learning with assumptions, but not all learning with simulation can be applied to every actual object. This is supported by research from Ferianto and Hidayati (2019) on the effectiveness of disaster management training through simulations on student preparedness [11].

Based on the results of the author's interviews with Semarang City BPBD employees, it was explained that the Semarang City Government had never conducted simulations to face the threat of floods during the Covid19 pandemic. The BPBD of Semarang City has just implemented a threat simulation. Whereas the simulation of facing disasters will provide knowledge about the attitudes that must be taken by the community to save themselves. research conducted which explains that prior to disaster simulation, respondents are not prepared to face disasters. However, after a simulation of dealing with a disaster threat was carried out, the respondents knew what to do.

There are regional policies that mainstream disaster risk assessment as a basis for development and investment considerations. The risks posed by disasters are the basis for consideration for the Semarang City Government to prioritize disaster management efforts in regional development. Therefore, the preparation of a disaster risk assessment covering all high-risk areas in 
the city of Semarang has been implemented. Disaster risk assessments contain risk maps for all disaster threats. This disaster risk study can also determine disaster management policies in regional disaster management planning and development and investment in the city of Semarang. The Semarang City Disaster Risk Assessment Document and the Semarang City Disaster Management Plan must be the priority of the Semarang City BPBD work program.

\section{CONCLUSION}

From the research results it can be concluded that the total flood area in the city of Semarang in 2020-2021 is 24,443 hectares. The northern part of Semarang City, because it has a sloping topography of approximately 05 meters above sea level, is located in Tugu District, West Semarang District, North Semarang District, Genuk District and Pedurungan District. Whereas areas that have low danger are in the southern part of Semarang City, which is located in Mijen District, Gunungpati District, Banyumanik District, Ngaliyan District and Candisari District with an altitude of approximately 200300 meters above sea level and has a steep topography.

The area's vulnerability to flooding is in the high category, while the community's ability to cope with flooding is in the Medium category. Based on the threat, vulnerability and vulnerability index, it can be seen that the risk of flooding in Semarang City is at a high level of risk. Residents of Semarang City who are disaster respond by adjusting or adapting to the situation. Preparedness efforts carried out by residents include housing relocation, building floors, hoarding, building houses on stilts, rehabilitating mangrove forests, building rainwater reservoirs, and biopori.

The author's recommendations to the government are: Formulate regulations for disaster management during the COVID-19 pandemic, Prepare evacuation sites according to health protocols, Formulate contingency plans for the threat of floods during a pandemic, Provide volunteers with help for Covid-19 patients, Improve coordination and cooperation in civilmilitary relations.

\section{REFERENCES}

[1] Badan Penanggulangan Bencana Kota Semarang. 2019. Rencana Penanggulangan Bencana Tahun 2019 - 2023. Kota Semarang: BPBD Jawa Tengah.

[2] Mona, Nailul. 2020. Konsep Isolasi Dalam Jaringan Sosial Untuk Meminimalisasi Efek Contagious (Kasus Penyebaran Virus Corona Di Indonesia). Jurnal Sosial
Humaniora Terapan 2(2):117-25. doi: 10.7454/jsht.v2i2.86.

[3] Ismanto, A., A. Wirasatriya, M. Helmi, A. Hartoko dan Prayogi. 2009. Model Sebaran Penurunan Tanah di Wilayah Pesisir Semarang. Jurnal Ilmu Kelautan Vol 14. No. 4 Desember $2009: 21-28$.

[4] Heryati, Sri. 2020. Peran Pemerintah Daerah Dalam Penanggulangan Bencana. Jurnal Pemerintahan Dan Keamanan Publik (JP Dan KP) 2(2):106-25.

[5] Findayani, April. 2015. Kesiapsiagaan Masyarakat dalam Penanggulangan Banjir di Kota Semarang. Dalam Jurnal Geografi Volume 12 Nomor 1: Semarang

[6] Abidin, H. Z., Andreas, H., Gumilar, I., Sidiq, T. P., \& Fukuda, Y. 2013. Land Subsidence In Coastal City Of Semarang (Indonesia): Characteristics, Impacts And Causes. Geomatics, Natural Hazards And Risk, 4(3), 226240.

[7] Kurniawati, Dwi, dan Suwito Suwito. 2019. Pengaruh Pengetahuan Kebencanaan Terhadap Sikap Kesiapsiagaan Dalam Menghadapi Bencana Pada Mahasiswa Program Studi Pendidikan Geografi Universitas Kanjuruhan Malang. JPIG (Jurnal Pendidikan Dan Ilmu Geografi) 2(2). doi: 10.21067/jpig.v2i2.3507.

[8] Lu, Ning, Kai Wen Cheng, Nafees Qamar, Kuo Cherh Huang, dan James A. Johnson. 2020. Weathering COVID19 Storm: Successful Control Measures of Five Asian Countries. American Journal of Infection Control 48(7):851-52. doi: 10.1016/j.ajic.2020.04.021.

[9] Habib, Muhammad, dan Abiyan Dzakwan. 2020. Urgensi Pembentukan Protokol Multi- Bencana Dalam Pandemi COVID- 19. CSIS Commentaries (April).

[10] BNPB. 2012. Pedoman Sistem Peringatan Dini Berbasis Masyarakat. Jakarta.

[11] Ferianto, Kusno, dan Uci Nurul Hidayati. 2019. Efektifitas Pelatihan Penanggulangan Bencana Dengan Metode Simulasi Terhadap Perilaku Kesiapsiagaan Bencana Banjir Pada Siswa Sman 2 Tuban. Jurnal Kesehatan Mesencephalon 5(2). doi: 10.36053/mesencephalon.v5i2.110. 